http://dx.doi.org/10.4314/jae.v16i2.6

\title{
Promoting Entrepreneurship and Diversification as a Strategy for Climate Change Adaptation among Rural Women in Anambra State, Nigeria
}

\author{
E.N. Ajani ${ }^{\star}$ and E.M. Igbokwe ${ }^{\star *}$ \\ E-mail Addresses: Iyneajani@gmail.com* and emigbo@yahoo.com** \\ Department of Agricultural Extension, Faculty of Agriculture, University of Nigeria, \\ Nsukka
}

\begin{abstract}
The study sought to identify enterprises carried out by rural women in Anambra State, Nigeria, which help them to adapt to climate change. Structured interview schedule was used to collect data from a sample of four hundred and sixty- two respondents. Data were analysed using percentage, mean scores and standard deviation. Majority (88.7\%) of the rural women were involved in multiple enterprises in order to cope with climate change. They were involved in enterprises such as planting of crops (88.1\%), marketing of farm produce (79.2\%), rearing of farm animals (42.2\%), petty trading (58.2\%), among others. The study also revealed that rural women made higher incomes per annum from enterprises such as petty trading $(M=\# 61,766.6)$, teaching ( $M=$ $\# 32,625.0)$, sale of cassava $(M=\# 16,878.0)$, sale of chicken ( $M=$ \#12,983.6), among others. The study recommends that appropriate measures should be taken to develop capabilities in order to empower rural women economically to cope with challenges of climate change. This will help to reduce poverty and vulnerability among rural women as well as enhance rural development.
\end{abstract}

Keywords: Entrepreneurship, Diversification, Climate change, Rural women, Anambra State, Nigeria

\section{Introduction}

Rural women's activities mainly range from petty trading, vocational enterprises, handicraft and farming to agro-processing. Women are also involved in production of agricultural raw materials for agro- industries. Almost all agricultural production and marketing activities including animal husbandry activities are performed by women. There is seemingly a good number of women in rural farming, processing and marketing. These income yielding informal economic activities make them indispensable in the process of rural development (Aspaas, 1998). There is however an observable change in the pattern of women's work in recent times as 
their participation is declining in agriculture but increasing in petty trading and other activities which according to Bryceson (2000) is called diversification out of agriculture. Islam (1997) identifies successive droughts as a result of climate change that depress income and hence increases the need for alternative incomes offering low-skill income as a distress-push factor.

Over the past two decades climate change has increasingly become recognised as a serious threat to sustainable development with current and projected impacts on areas such as environment, agriculture, energy, human health, food security, economic activity, natural resources and physical infrastructure. Although climate change impacts will affect all countries, its impacts will be differently distributed among different regions, generations, age classes, income groups, occupations and gender (International Panel on Climate Change (IPCC), 2001). The poor who are mostly women in developing countries will be disproportionately affected (Drexhage, 2006).

Women are responsible for $65 \%$ of household food production in sub-Saharan Africa. The burden of food crisis, declining affordable energy sources, and impoverishment induced by climate change are disproportionately borne by women because of their multiple roles as producers and family caretakers (Organization for Economic Cooperation and Development (OECD), 2008). There is also evidence that since women in developing countries have primary responsibility of providing for their families. They are more reliant on natural resources and are thus more careful stewards of them and the environment (Price Waterhouse Coopers (PWC), 2008). They have been engaging in various efforts that qualify as climate change mitigation and adaptation activities. In several rural areas of sub-Saharan Africa, women are responsible for feeding their families and are therefore more dependent on natural resources such as land, wood and water. However, their access to these resources is limited. They are also denied full access to loans, education and information.

According to Denton (2002), the potential of women as agents of change for climate mitigation and adaptation remains untapped. Their extensive theoretical and practical knowledge of the environment and resource conservation is not given due consideration. In terms of economic participation, they are not paid for the environmental services that they already provide (example, reforestation). The potential contribution to climate mitigation by being part of the economic cycle is not sufficiently exploited.

It is increasingly recognised that empowering women, children and other marginalised groups is beneficial not only as a policy in itself, but also as a means of strengthening the effectiveness of climate change measures (United Nations Development Programme (UNDP), 2009; Deutsche Gesellschaft für Technische Zusammenarbeit (GTZ), 2010). However, there are several ways of promoting women's economic participation while also counteracting climate change. This can be achieved through diversification in farm and non-farm enterprises which 
enables them to cope with the challenges of climate change. The economic empowerment of women through climate mitigation and adaptation fosters economic growth and socioeconomic development, reduces poverty, keeps environmental problems in check, and increases the potential for adaptation, which is to the benefit of both women and men. Enhancing the economic empowerment of women is a catalyst for development, which helps boost a country's economic growth, promotes the socioeconomic development not only of women, but of the entire population, and helps reduce poverty (OECD, 2008; World Bank, 2006).

Climate change and its impact on income security for the family increases the potential for domestic violence, as it shatters the image of the man as breadwinner, which can cause psychological stress (Rodenberg, 2009). With regards to climate adaptation, it should be noted that women often do not have much of a say in decisions taken by the family or the community and are therefore unable to diversify cultivation (Rodenberg, 2009). Furthermore, it is usually women who are responsible for collecting water and fuel (example firewood) for the household. The scarcity of these resources induced by climate change increases a woman's workload and time poverty, burdened as she already is by the many roles she has to play. She is consequently left with no time for income-generating activities, education, training or participation in community decision making processes. In overall terms, climate change intensifies the existing economic and social gender disparities (Rodenberg, 2009). Greater decision-making powers for women at the family and community level with regard to agricultural cultivation and the farming of new and more resistant crops could increase agricultural production, leading to greater food security, production and marketing of surpluses and ultimately to a source of income.

This raises the following questions: What are the enterprises engaged by rural women in order to adapt to climate change? And what are the enterprises where the activities of rural women dominate in terms of greater income to enhance climate change adaptation?

The specific objectives were to:

(i) identify types of enterprises engaged in by rural women for climate change adaptation; and

(ii) ascertain enterprises where the activities of rural women dominate for increased income.

\section{Methodology}

The study was carried out in Anambra State, Nigeria. There are four agricultural zones in the state, namely; Aguata, Anambra, Awka and Onitsha. The estimated population of rural women in Anambra State is 2.13 million (NPC, 2006). The population of the study comprised rural women in the four agricultural zones. All 
the four agricultural zones were purposively used for the study. Anambra zone is made up of four (4) extension blocks comprising 45 circles, Awka zone comprises five (5) blocks and 35 circles, while Aguata zone is made up of six (6) extension blocks, comprising 45 circles. There are also six (6) extension blocks comprising 30 circles in Onitsha zone. Two (2) rural blocks were selected from each of the zones, while three (3) circles were selected from each of the blocks using simple random sampling. In each of the circles, 20 rural women were selected using simple random sampling. Eight (8) blocks and 24 circles, comprising 480 respondents were supposed to be used for the study. Eighteen copies of the questionnaire were not filled properly and were dropped leaving 462 used for analysis. Data for the study were collected using interview schedule/questionnaire. Percentage, mean score and standard deviation were used for data analysis.

\section{Results and Discussion}

\section{Socio-economic characteristics of respondents}

Majority (60.5\%) of the respondents were within the age range of 40-59 years (Table 1). The mean age of the respondents was 50.0 years. This implies that majority of the respondents were middle aged and in their productive years, hence greater involvement in both farm and non-farm activities.

A greater proportion (69.3\%) of the respondents were married. This shows that most of the respondents have husbands who may be providing support for them in their activities, either financially or otherwise. Oberhauser and Pratt (2004) note that married people have responsibility for provision of household needs of their families hence greater involvement in occupational diversification for economic empowerment.

Data on level of education of the respondents (Table 1) reveal that majority $(93.3 \%)$ were literate. The mean year of formal education was 9 years. This implies that with a majority of the respondents having formal education they are better equipped to enter into various occupations. The findings agree with Ranjan (2006) who asserts that level of education increases participation rate in occupations for rural women. Educated rural women are likely to possess skills which facilitate successful involvement in non-farm activities.

Majority (62.8\%) of the respondents had a household size of 1-5 persons. The mean household size was 5 persons. Size of household can be a key variable in determining whether the respondents should diversify their occupations. Large household size could serve as source of labour for farming activities. This is in agreement with Economic and Social Commission for Asia and the Pacific (ESCAP), (1999) which reports that rural families are characterized by large family size, demanding for greater involvement in occupational diversification in order to meet up with household responsibilities. 
About $45 \%$ of the respondents had over 19 years of farming experience with mean farming experience of 20.1 years. This implies that most of the respondents have been farming for quite a long period of time. This can help them to diversify more into farm activities such as crop and livestock production. Rural women with many years of experience in farming are more likely to diversify into agricultural activities making use of wealth of experiences they have acquired over the years.

Majority (52.0\%) of the respondents reported farm sizes of 1.1-2.0 ha with a mean farm size of 1.3 hectares. This indicates that majority of the respondents were small-scale farmers who produce at a subsistence level. The finding is not surprising considering the high population density of 4.18 million in the State. This is in agreement with Africa Fertilizer Summit (2006) which reports that small scale farmers cultivate between 0.8 and 1.3 hectares of land in forest areas of the country.

Majority (84.6\%) of the respondents were involved in crop production, while $51.9 \%$ of them were involved in both crop and livestock production. This implies that the respondents were involved in both crop and livestock production. This is to enable them sustain their families economically. The ability to be involved in both crop and livestock production may serve as an avenue for raising capital for non-farm activities. The finding is in agreement with Reardon (1997) who concludes that most rural women depend on crop and livestock activities for their incomes. This in itself is a form of diversification and insurance against risk. 
TABLE 1

Percentage distribution of socio-economic characteristics of the respondents $(n=462)$

\begin{tabular}{|c|c|c|c|}
\hline Variable & Percentage & Mean (M) & $\begin{array}{l}\text { Standard } \\
\text { deviation (SD) }\end{array}$ \\
\hline \multicolumn{4}{|l|}{ Age (years) } \\
\hline $20-29$ & 5.2 & \multirow{6}{*}{50.0} & \multirow{6}{*}{11.72} \\
\hline $30-39$ & 14.2 & & \\
\hline $40-49$ & 27.1 & & \\
\hline $50-59$ & 33.4 & & \\
\hline $60-69$ & 15.9 & & \\
\hline 70 and above & & & \\
\hline \multicolumn{4}{|l|}{ Marital status } \\
\hline Single & 5.4 & & \\
\hline Married & 69.3 & & \\
\hline \multirow{2}{*}{\multicolumn{4}{|c|}{ Years spent in school (years) }} \\
\hline & & & \\
\hline No formal education & 6.7 & 8.5 & 4.53 \\
\hline Primary school attempted & 12.5 & & \\
\hline Primary school completed & 28.8 & & \\
\hline Secondary school attempted & 11.2 & & \\
\hline Secondary school completed & 25.3 & & \\
\hline OND/NCE holders & 8.9 & & \\
\hline HND/first degree & 6.6 & & \\
\hline $\begin{array}{l}\text { Household size (numbers) } \\
1-5\end{array}$ & 62.8 & & \\
\hline $6-10$ & 36.8 & 4.9 & 1.82 \\
\hline 11 and above & 0.4 & & \\
\hline $\begin{array}{l}\text { Farming experience (years) } \\
0-9\end{array}$ & 206 & \multicolumn{2}{|c|}{ Farming experience (years) } \\
\hline $10-19$ & 34.9 & & \\
\hline $20-29$ & 21.2 & & \\
\hline $30-39$ & 13.2 & 20.1 & 13.62 \\
\hline $\begin{array}{l}40-49 \\
50 \text { and above }\end{array}$ & 6.6 & & \\
\hline \multicolumn{4}{|l|}{$\begin{array}{l}50 \text { and above } \\
\text { Size of farmland (hectares) }\end{array}$} \\
\hline$<1.0$ & 35.7 & & \\
\hline $1.1-2.0$ & 51.7 & & \\
\hline $2.1-3.0$ & 7.8 & 1.3 & 1.08 \\
\hline $3.1-4.0$ & 3.5 & & \\
\hline $4.1-5.0$ & 1.3 & & \\
\hline \multicolumn{4}{|l|}{ Type of farming ${ }^{*}$} \\
\hline Crop production & 84.6 & & \\
\hline Livestock production & 43.5 & & \\
\hline Mixed farming & 51.9 & & \\
\hline
\end{tabular}




\section{Types of enterprises engaged in by rural women for climate change adaptation}

Majority (88.1\%) of the respondents were involved in planting of crops, $79.2 \%$ of them were involved in marketing of farm produce, about $42 \%$ kept goat and sheep, $40.5 \%$ kept chicken, among others (Table 2). This implies that the respondents were involved in mixed farming. This is to enable them sustain their families economically and adapt to climate change. This will also help them to guard against crop failures resulting from variations in climate as well as providing safety nets for economic empowerment.

A greater proportion $(58.2 \%)$ of the respondents were involved in petty trading, $10.4 \%$ were involved in tailoring, $6.9 \%$ were teachers, $6.2 \%$ were involved in making of confectioneries, while $5.6 \%$ of them were involved in hair dressing/weaving of hairs, among others (Table 2). This implies that the respondents were involved in both farm and non-farm enterprises. This is to enable them obtain additional income to empower themselves financially in order to cope with climate change. The findings are in line with Haggblade (1999) who reports that women dominate many of the non-farm activities such as petty trading, tailoring and many services that will grow most rapidly during structural transformation. Continuing, he notes that they also hold a major interest in many of the declining rural non-farm occupations such as basket making. Consequently, women will be key actors in the economic transition of Africa's rural economy. 
TABLE 2

Percentage distribution of respondents according to their involvement in enterprises for climate change adaptation $(n=462)$

\begin{tabular}{lc}
\hline Enterprises & Percentage \\
\hline Planting of arable crops (yam, cocoyam, & 88.1 \\
cassava, maize, vegetables and rice) & 79.2 \\
Marketing of farm produce & 2.6 \\
Processing of cassava into gari & 2.6 \\
Processing of cassava into dough & \\
(fermented flour) & 3.5 \\
Processing of cassava into chips/flour & 4.7 \\
Processing of maize into pap and flour & 3.0 \\
Processing of oil palm into palm oil & 3.4 \\
Processing of oil palm into palm kernel & \\
oil & 42.2 \\
Rearing of farm animals such as goat & \\
and sheep & 40.5 \\
Rearing of chicken & 14.7 \\
Rearing of turkey & 5.0 \\
Pig farming & 0.2 \\
Snail farming & 0.4 \\
Fish farming & 3.5 \\
Handicrafts such as making of brooms & 2.4 \\
Making of baskets & 0.9 \\
Making of hand fans & 0.4 \\
Making of beads & \\
Petty trading on food items such rice, & 58.2 \\
beans, gari and palm oil & 10.4 \\
Tailoring/making of dresses & \\
Making of confectioneries such as cake, & 6.2 \\
chin-chin, meat pie and buns & 2.5 \\
Making of soap and pomade & 3.6 \\
Frying of beans balls, yams and & \\
Hair dressing/weaving of hair & 5.6 \\
Teaching & 6.9 \\
Traditional birth attendance & 0.9 \\
Cablic service & 5.2 \\
Wage labour & 3.2 \\
*Multiple responses & 0.6 \\
\hline
\end{tabular}




\section{Estimated income from major enterprises}

The respondents obtained income mostly from production of cassava and rearing of livestock such as poultry, goat and sheep, petty trading, tailoring, teaching, public service, as shown in Table 3. A greater proportion $(61.0 \%)$ of the respondents earned less than $\$ 20,000$ from sale of cassava, about $18 \%$ earned \#20,001- $\$ 40,000$, while $9.6 \%$ and $8.6 \%$ earned $\$ 40,001-60,000$ and 60,001 and above respectively. Also, $3.2 \%$ of the respondents earned $\$ 80,001$ and above. The estimated mean income was $\$ 12,295$. The respondents earned high income from sale of cassava which is quite impressive. This could be attributed to cassava being a staple food and constitutes most of meals served by most families in the study area. This confirms Ozor, Madukwe, Onokala, Enete, et al (2010) who note that cassava is a major crop grown in Southern Nigeria.

The results also show that $88.3 \%$ of the respondents obtained less than $\$ 40,000$ from sale of chicken, $10.3 \%$ obtained $40,001-8000$, while about $1 \%$ and $0.4 \%$ obtained $\$ 80,001-120,000$ and over $\$ 120,000$ respectively. The estimated mean income from chicken farming was $\$ 12,983.6$. This implies that the respondents acquire large sum of money from sale of chicken. This could be attributed to the fact that most households in rural areas consume smaller proportion of reared livestock. The respondents keep the chicken mostly for sale to obtain money which they need to meet up with their family responsibilities.

Majority (88.1\%) of the respondents earned less than $\$ 30,000$ from goat and sheep farming, $7.2 \%$ earned $\$ 30,001-\$ 60,000$, while $4.3 \%$ and $0.4 \%$ earned $\$ 60,001-\$ 90,000$ and over $\$ 90,000$ respectively. The estimated mean income from goat and sheep farming was $\$ 9,822.7$. The respondents made high returns from sale of goat and sheep. The findings are in agreement with IFAD (1995) which observed that women's earnings from crop and livestock production account for a larger share of family income.

Distribution of respondents according to estimated income from petty trading is also shown in Table 3 . This indicates that $86.6 \%$ of the respondents earned less than $\$ 100,000$ from petty trading, $6.7 \%$ earned $\$ 100,001-200,000$, about $3 \%$ earned $200,001-\$ 300,000$, while $2.4 \%$ and $1.2 \%$ earned over $\$ 400,000$ and \#300,001- $\$ 400,000$ respectively. The mean income from petty trading was \#61,766.6. This implies that the respondents got higher incomes from petty trading. This could make the respondents to diversify more into different forms of petty trades in order to obtain high incomes. A greater proportion $(95.0 \%)$ of the respondents earned less than $\$ 50,000$ from tailoring, $4.1 \%$ earned $\$ 50,001$ $\$ 100,000$, while about $1 \%$ and $0.2 \%$ earned $\$ 100,001-\$ 150,000$ and $\$ 150,001$ \#200,000 respectively. The mean income from tailoring was $\$ 6,032$.

The respondents (93.1\%) involved in teaching earned less than $\$ 200,000$, followed by $5.1 \%$ who earned above $\$ 400,000$. Also, $1.2 \%$ earned $\$ 200,001$ $\$ 300,000$, while $0.6 \%$ earned $\$ 300,001-\$ 400,000$. The mean income from teaching was $32,625.5$. The income earned by the respondents from teaching is 
quite high, this could be attributed to the fact that most of the respondents were placed on monthly salary which were mostly paid by the government.

A greater proportion (94.8\%) of the respondents earned less than $\$ 100,000$ from public service, while $5.2 \%$ earned above 100,000 . The mean income was 13,878.8. A greater proportion (97.8\%) of the respondents earned less than $\$ 100,000$ from catering services, $1.2 \%$ earned over $\$ 300,000$, while $1.0 \%$ earned $\$ 100,001-\$ 200,000$. The mean income was $\$ 8,008.7$. It implies that the enterprises serve as major areas in generating income for the rural women and efforts should be geared towards modernizing agriculture especially value chain enterprises as well as providing labour saving technologies. This is to enable them cope with climate change as they diversify into various occupations.

TABLE 3

Distribution of respondents based on enterprises that yield higher estimated income in $2010(n=462)$

\begin{tabular}{|c|c|c|c|}
\hline 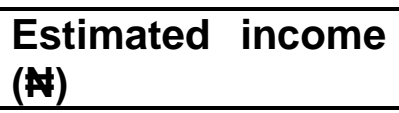 & Percentage & $\begin{array}{l}\text { Mean } \\
(\mathrm{M})\end{array}$ & Standard deviation (SD \\
\hline \multicolumn{4}{|l|}{ Cassava } \\
\hline$<20,000$ & 61.0 & & \\
\hline $20,001-40,000$ & 17.6 & & \\
\hline \multirow[t]{2}{*}{$40,001-60,000$} & 9.6 & & 8988.00 \\
\hline & & 16878.0 & \\
\hline $60,001-80,000$ & 8.6 & & \\
\hline \multirow{2}{*}{\multicolumn{4}{|c|}{ Chicken }} \\
\hline & & & \\
\hline$<40,000$ & 88.3 & & \\
\hline $40,001-80,000$ & 10.3 & 12983.6 & 21605.76 \\
\hline $80,001-120,000$ & 1.0 & & \\
\hline 120,001 and above & 0.4 & & \\
\hline $60,001-80,000$ & 0.7 & & \\
\hline \multicolumn{4}{|l|}{$\begin{array}{l}\text { Goat and sheep } \\
\text { farming }\end{array}$} \\
\hline$<30,000$ & 88.1 & & \\
\hline $30,001-60,000$ & 7.2 & 9822.7 & 18220.66 \\
\hline $60,001-90,000$ & 4.3 & & \\
\hline 90,001 and above & 0.4 & & \\
\hline \multicolumn{4}{|l|}{ Petty trading } \\
\hline$<100,000$ & 86.6 & & \\
\hline $100,001-200,000$ & 6.7 & & \\
\hline $200,001-300,000$ & 3.1 & $61,766.6$ & 109260.80 \\
\hline $300,001-400,000$ & 1.2 & & \\
\hline 400,001 and above & 2.4 & & \\
\hline
\end{tabular}




\begin{tabular}{lccc}
\hline Tailoring & 95.0 & & \\
$<50,000$ & 4.1 & 6032.0 & 20829.05 \\
$50,001-100,000$ & 0.7 & & \\
$100,001-150,000$ & 0.2 & & \\
$150,001-200,000$ & 93.1 & & \\
Teaching & 1.2 & 32625.5 & \\
$<200,000$ & 0.6 & & \\
$200,001-300,000$ & 5.1 & & \\
$300,001-400,000$ & & & \\
400,001 and above & 94.8 & & \\
Public service & & & \\
$<100,000$ & 0.2 & 13878.79 & \\
& 1.8 & & \\
$100,001-200,000$ & 3.2 & & \\
$200,001-300,000$ & & & \\
300,001 and above & &
\end{tabular}

\section{Conclusion and Recommendations}

Rural women were involved in diversification of enterprises in order to cope with climate change. They were involved in various enterprises such as planting of crops, marketing of farm produce, processing of farm produce, rearing of farm animals, petty trading, tailoring, teaching, hair dressing, public service, wage labour, among others. Diversification of enterprises also generates additional income for economic empowerment of rural women. The economic empowerment of women for climate change adaptation creates an opportunity for poverty reduction and rural development. Measures to promote the economic participation of women through capacity building should be integrated into climate adaptation initiatives. Adequate measures that provide present and future benefits are required to increase the resilience of rural women's livelihoods, diminish gender inequality, increase awareness of climate change effects and prepare them for future changes. However, for a prospect to be made, success will be tied to an integrated approach and to institutional and political measures that are required to create the basic structural conditions necessary for broad-based and sustainable economic empowerment. 


\section{References}

Africa Fertilizer Summit (2006). Nigeria fertilizer strategy report. International Conference Centre, Abuja, pp. 2-15.

Aspaas HR (1998). Heading households and heading businesses: Rural Kenyan women in the informal sector. Prof. Geographer, vol.50(2), pp.192-204.

Bryceson, D. F. (2000). Rural Africa at the crossroads: Livelihood practices and policies. Natural Resources Perspectives, Number 52, pp.1-4.

Denton, F. (2002). Climate change vulnerability, impacts, and adaptation: Why does gender matter? Gender and Development, vol. 10 (2), pp. 10-20.

Drexhage, J. (2006). The World Conservation Union (IUCN) Climate Change Situation. Analysis. Final Report. IISD-IUCN, Switzerland.

Economic and Social Commission for Asia and the Pacific (ESCAP) (1999). Strengthening income generating opportunities for rural women in selected Asian countries. (Available at www.unescap.org/rural/doc/women/vi.rep of EGM.PDF).

Gesellschaft für Technische Zusammenarbeit (GTZ) (2010). Climate Change and Gender: Economic Empowerment of Women through Climate Mitigation and Adaptation?', Working Paper, Governance and Democracy Division, GTZ Governance Cluster http://www.climatehealthconnect.org/sites/climatehealthconnect.org/files/res ources/17353 diskussionspapierenlayoutgc12941558.pdf

HaggbBlade, S. (1999). Farm- non-farm linkages in rural sub-Saharan Africa. World Development, vol.17 (8), pp.1173 - 1201.

International Fund for Agricultural Development (IFAD) (1995). Rural women's contribution to household income. Rome: IFAD, pp.1-2.

International Panel on Climate Change (IPCC)(2001). Summary for Policymakers. Climate Change 2001: Impacts, Adaptation, and Vulnerability. Report of Working Group II of the IPCC. http://www.ipcc.ch

Islam, N. (1997). The non-farm sector and rural development: Review of issues and evidence. Food, Agriculture and the Environment, Discussion paper 22, IFPRI, Washington, DC.

National Population Commission (NPC) (2006). National Population census figure, Abuja, Nigeria.

Oberhauser, A.M, Pratt, A. (2004). Women's collective economic strategies and political transformation in rural south Africa. Journal of Gender Planning and Culture, vol.11(2), pp. 206-228. 
Organization for Economic Cooperation and Development (OECD) (2008). Gender and Sustainable Development, maximizing the economic, social and environmental role of women (Paris), pp. 73-74.

Ozor, N., Madukwe, M.C., Onokala, P.C., Enete, A., Garforth, C.J., Eboh, E., Ujah, O. and Amaechina, E. (2010). A framework for agricultural adaptation to climate change in Southern Nigeria. A Development Partnerships in Higher Education (DelPHE) 326 project, Executive Summary Supported by DFID and the British Council, African Institute for Applied Economics, Enugu, pp. 1-3.

Price Waterhouse Coopers (PWC) (2008). What is Success in a Connected World? Empowering Women to Empower the Earth, Price Waterhouse Coopers

http://www.pwc.com/en GX/gx/women-atpwc/assets/empoweringwomen.pdf

Ranjan, S. (2006). Occupational diversification and access to rural employment: Revisiting the non-farm employment debate Munich Personal Repec Archive (MPRA) paper Number 7870, pp.4-8.

Reardon, T. (1997). Using evidence of household income diversification to inform study of the rural non-farm labour market in Africa. World Development, vol.25 (5), pp.735-748.

Rodenberg, B. (2009). Climate Change Adaptation from a Gender Perspective. German Development Institute, 'Es sind die Machtverhältnisse, die Frauen für den Klimawandel verwundbarer machen', Böll THEMA, Heft 2/2009, p.14<http://www.boell.de/downloads/publikationen/BoellThema_2.2009_ab Reader7kommentierbar.pdf> (07.01.2010)

United Nations Development Programme (UNDP)(2009). Resource Guide on Gender and Climate Change, UNDP

http://content.undp.org/go/cmsservice/download/asset/?asset id=1854911

World Bank (2006). Gender Equality as Smart Economics: A World Bank Group Gender Action Plan (Fiscal years 2007-10) $<$ http://siteresources.worldbank.org/INTGENDER/Resources/GAPNov2.pdf $>$ (26.01.2010). 